Research note

\title{
New records of the Californian lancelet Branchiostoma californiense (Cephalochordata: Branchiostomidae) from the Pacific coast of Mexico
}

\author{
Nuevos registros de la lanceta de California Branchiostoma californiense (Cephalochordata: \\ Branchiostomidae) de la costa pacífica de México
}

Cristian Moisés Galván-Villa*, Eduardo Ríos-Jara, Manuel Ayón-Parente

Laboratorio de Ecosistemas Marinos y Acuicultura, Departamento de Ecología, Centro Universitario de Ciencias Biológicas y Agropecuarias, Universidad de Guadalajara, Camino Ing. Ramón Padilla Sánchez \#2100, Predio Las Agujas, 45110 Zapopan, Jalisco, Mexico

Received 22 July 2016; accepted 10 June 2017

Available online 1 December 2017

\begin{abstract}
A number of specimens of the Californian lancelet, Branchiostoma californiense Andrews, 1893 were found in Isla Melendres, Sinaloa and Bahía Chamela, Jalisco, in the Mexican Pacific. The specimens were collected with a biological dredge on sandy bottoms. Some morphometric and meristic characters of the collected specimens are described and discussed herein. This is the first record of the species for the Bahía Chamela in the central Mexican Pacific and second for the Sinaloa state in the Gulf of California, confirming their distribution along the Eastern Pacific from the coast of California coast, USA to Panama. However, an extensive area of the southern Mexican Pacific ( $\sim 1,500 \mathrm{~km}$ from Colima to Chiapas) have scarce records of this species, this possibly due to the lack of sampling effort on this group in the area.
\end{abstract}

(C) 2017 Universidad Nacional Autónoma de México, Instituto de Biología. This is an open access article under the CC BY-NC-ND license (http://creativecommons.org/licenses/by-nc-nd/4.0/).

Keywords: Amphioxus; New records; Distribution; Central Mexican Pacific

\section{Resumen}

Algunos especímenes de la lanceta de California Branchiostoma californiense Andrews, 1893 fueron encontrados en la isla Melendres (Sinaloa) y en la bahía Chamela (Jalisco), en el Pacífico mexicano. Los ejemplares fueron recolectados con una draga biológica en fondos arenosos. Algunos caracteres morfométricos y merísticos de los especímenes encontrados son descritos y discutidos en este trabajo. Este es el primer registro de la especie para la bahía Chamela en el Pacífico central mexicano y el segundo para el estado de Sinaloa, dentro del golfo de California, lo que permite confirmar su distribución a lo largo del Pacífico oriental desde la costa de California ( 8EUA) hasta Panamá. Sin embargo, en una extensa área del sur del Pacífico mexicano ( $\sim 1,500 \mathrm{~km}$ desde Colima hasta Chiapas) se encuentran escasos registros de esta especie, posiblemente por la falta de esfuerzo de muestreo sobre este grupo en esta área.

(C) 2017 Universidad Nacional Autónoma de México, Instituto de Biología. Este es un artículo Open Access bajo la licencia CC BY-NC-ND (http://creativecommons.org/licenses/by-nc-nd/4.0/).

Palabras clave: Anfioxos; Nuevos registros; Distribución; Pacífico central mexicano

The lancelets or amphioxi are small chordates with a cosmopolitan distribution, inhabiting shallow marine and brackish waters, mainly associated with coarse sediments such as sand, gravel, or shell material (Da Silva, Tavares,

\footnotetext{
* Corresponding author.

E-mail address: cmgv1982@yahoo.com.mx (C.M. Galván-Villa).

Peer Review under the responsibility of Universidad Nacional Autónoma de México.
}

\& Soares-Gomes, 2008; Richardson \& McKenzie, 1994). Currently, lancelets are important for phylogenetic studies of vertebrates due to its phylogenetic proximity with the vertebrate clade (García-Fernández \& Benito-Gutiérrez, 2009; Gee, 2006; Vargas \& Dean, 2010). The chordate family Branchiostomidae is composed of 2 valid genera: Branchiostoma and Epigonichthys. The genus Branchiostoma is the most diverse, with 23 valid species, 2 of them (Branchiostoma californiense Andrews, 1893 and Branchiostoma elongatum Sundevall, 
1853) distributed throughout the Tropical Eastern Pacific (Del Moral-Flores, Guadarrama-Martínez, \& Flores-Coto, 2016; Poss \& Boschung, 1996). According to Gill (1895), the species in this genus are characterized by bearing bilateral gonads, a rayed sympodium, low dorsal fin, and sagittiform expansion of the caudal fin membranes.

B. californiense has been previously recorded in the California coast, USA, the Gulf of California, Jalisco, and Oaxaca 9, Mexico (Beebe \& Tee-Van, 1941; Del Moral-Flores et al., 2016; Hubbs, 1922; 10 Poss \& Boschung, 1996), Corinto harbor, Nicaragua 11(Poss \& Boschung, 1996), the Gulf of Nicoya, Costa Rica (Vargas \& Dean, 2010), and 2 Chame Point in Panama (Meek \& Hildebrand, 1923); the other species B. elongatum has been reported from Chile, Peru, and the Galapagos islands (Poss \& Boschung, 1996; Snodgrass \& Heller, 1905; Vergara, Oliva, \& Riascos, 2012). Studies of lancelet communities in the Mexican Pacific region are limited. As part of a study on the diversity of the marine fauna of the Sanctuary of Bahía Chamela and the coast of Sinaloa, some specimens identified as $B$. californiense were collected and these represent records from the southeast area of the Gulf of California and the central Mexican Pacific.

Four specimens of B. californiense were collected from the sandy bottom of Bahía Chamela, Jalisco, in the central Mexican Pacific and 1 more from Isla Melendres, Sinaloa, in the southeast Gulf of California. The specimens from Bahía Chamela were collected in October 2013 from the shallow subtidal zone (5-8 m deep) in 3 different sites and the specimen from Isla Melendres was collected in August 2015. Sediment samples were taken with a rectangular biological dredge $(26 \times 44 \mathrm{~cm}$, mesh size $=2.5 \mathrm{~cm}$, and cod-end mesh size $=1.3 \mathrm{~cm}$ ) conducted on lineal trawling for $5 \mathrm{~min}$. All specimens were fixed in $5 \%$ formalin, later preserved in $70 \%$ ethanol and subsequently deposited in the invertebrate collection of the Laboratory of Marine Ecosystems and Aquaculture (LEMA, for its acronym in Spanish), Centro Universitario de Ciencias Biológicas y Agropecuarias, Universidad de Guadalajara (Zapopan, Mexico). Identification of specimens was based on the descriptions given by Hubbs (1922) and Kirkaldy (1895).

Phylum Chordata Haeckel, 1874

Subphylum Cephalochordata Owen, 1846

Class Leptocardii Müller, 1845

Order Amphioxiformes Anonymous

Family Branchiostomatidae Bonaparte, 1846

Genus Branchiostoma Costa, 1834

B. californiense Andrews, 1893 (Fig. 1)

Material examined. LEMA-CCC1 $(1,25.2 \mathrm{~mm}$ TL (total length)), $19^{\circ} 32^{\prime} 04^{\prime \prime} \mathrm{N} 105^{\circ} 05^{\prime} 05^{\prime \prime} \mathrm{W}, 7 \mathrm{~m}$, Bahía Chamela, Jalisco, Mexico, 10 October 2013. LEMA-CCC2 (1, $28.1 \mathrm{~mm}$ TL), $19^{\circ} 33^{\prime} 20^{\prime \prime} \mathrm{N} 105^{\circ} 06^{\prime} 22^{\prime \prime} \mathrm{W}, 8 \mathrm{~m}$, Bahía Chamela, Jalisco, Mexico, 10 October 2013. LEMA-CCC3 (2, 24.1-26.1 mm TL), $19^{\circ} 33^{\prime} 23^{\prime \prime} \mathrm{N} 105^{\circ} 06^{\prime} 20^{\prime \prime} \mathrm{W}, 5 \mathrm{~m}$, Bahía Chamela, Jalisco, Mexico, 12 October 2013. LEMA-CCC4 (1, $40.1 \mathrm{~mm}$ TL), $24^{\circ} 57^{\prime} 16^{\prime \prime} \mathrm{N} 108^{\circ} 03^{\prime} 5^{\prime \prime} \mathrm{W}, 1 \mathrm{~m}$, Isla Melendres, Sinaloa, Mexico, 6 August 2015.

Description. Body elongate. Ratio of body length to body depth 11.7 (10.4-13.2). Ratio of preatriopore length to

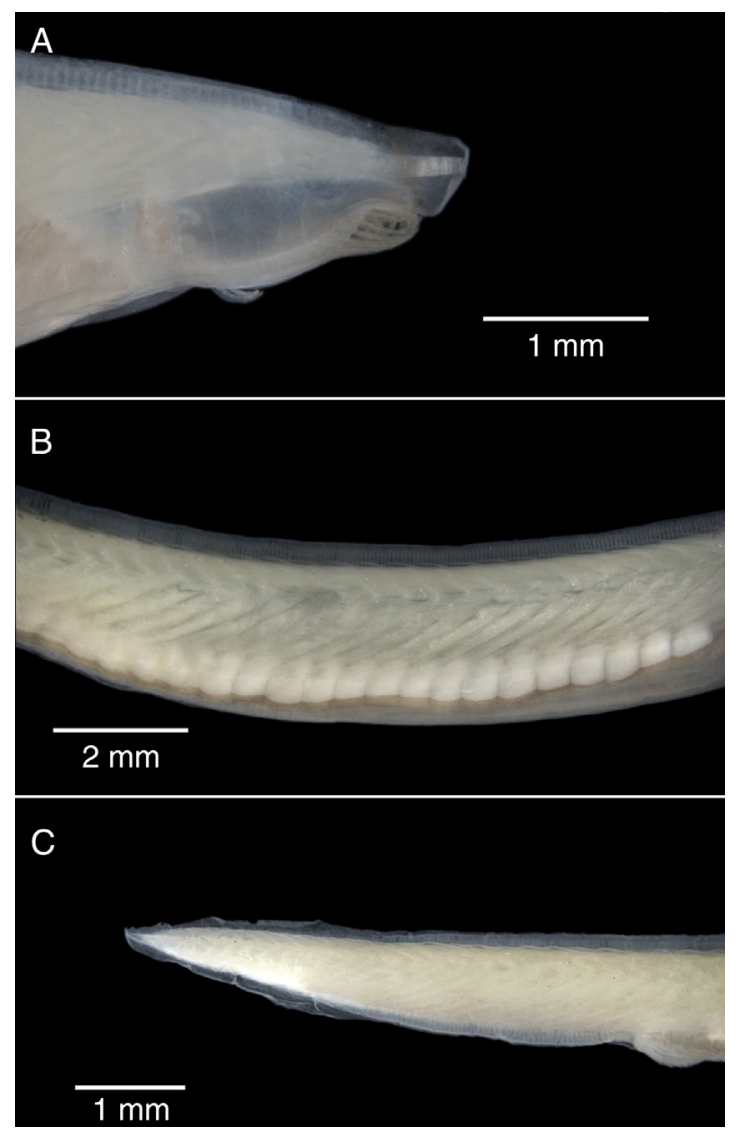

Figure 1. Lateral view of the external features of Branchiostoma californiense (LEMA-CCC2) from Bahía Chamela. (A) Head region; (B) trunk region; 1 (C) tail region.

postatriopore length 2.42 (2.2-2.6). Notochord extends forward of the oral hood and forms a well-developed rostral process. Buccal region with numerous fine cirri (up to 40), some of them longer than the tip of the rostrum. Rostral fin thickened and round termination. Myotome formula: preatriopore 43 $(39-46)+$ atriopore-anal $17(16-19)+$ postanal $9(9-10)=$ total 69 (66-72). Dorsal fin of moderate height. Dorsal fin-chambers 364 (343-395). Preanal fin-chambers 58 (56-61). Ratio of body length to body depth 12.06 (10.4-13.36). Caudal fin with expansions of dorsal and ventral fins long and shallow. Anus located far behind middle of lower lobe of caudal fin. Color of body white and fins translucent.

Distribution. Coast of California, USA to Chame Point, Panama (Poss \& Boschung, 1996).

3Although $B$. californiense is widely distributed and abundant along the tropical eastern Pacific (Fig. 2) 12. 13The lack of information 4 is 5 due to 6 the difficulty of collecting them because they 14 have small size and live 15 buried in sandy bottoms. This is the second record of lancelets for the coast of Jalisco in the central Mexican Pacific, previous record was collected in 1935 in Bahía Tenacatita (LACM-22314); since then it had not been reported again. A previous record in Sinaloa corresponds to 1 specimen collected in Bahía Mazatlán, near to the Isla Venados (Poss \& Boschung, 1996), approximately $250 \mathrm{~km}$ south of Isla Melendres (where the specimen of this work was found). Records of B. californiense are concentrated in 3 regions: 


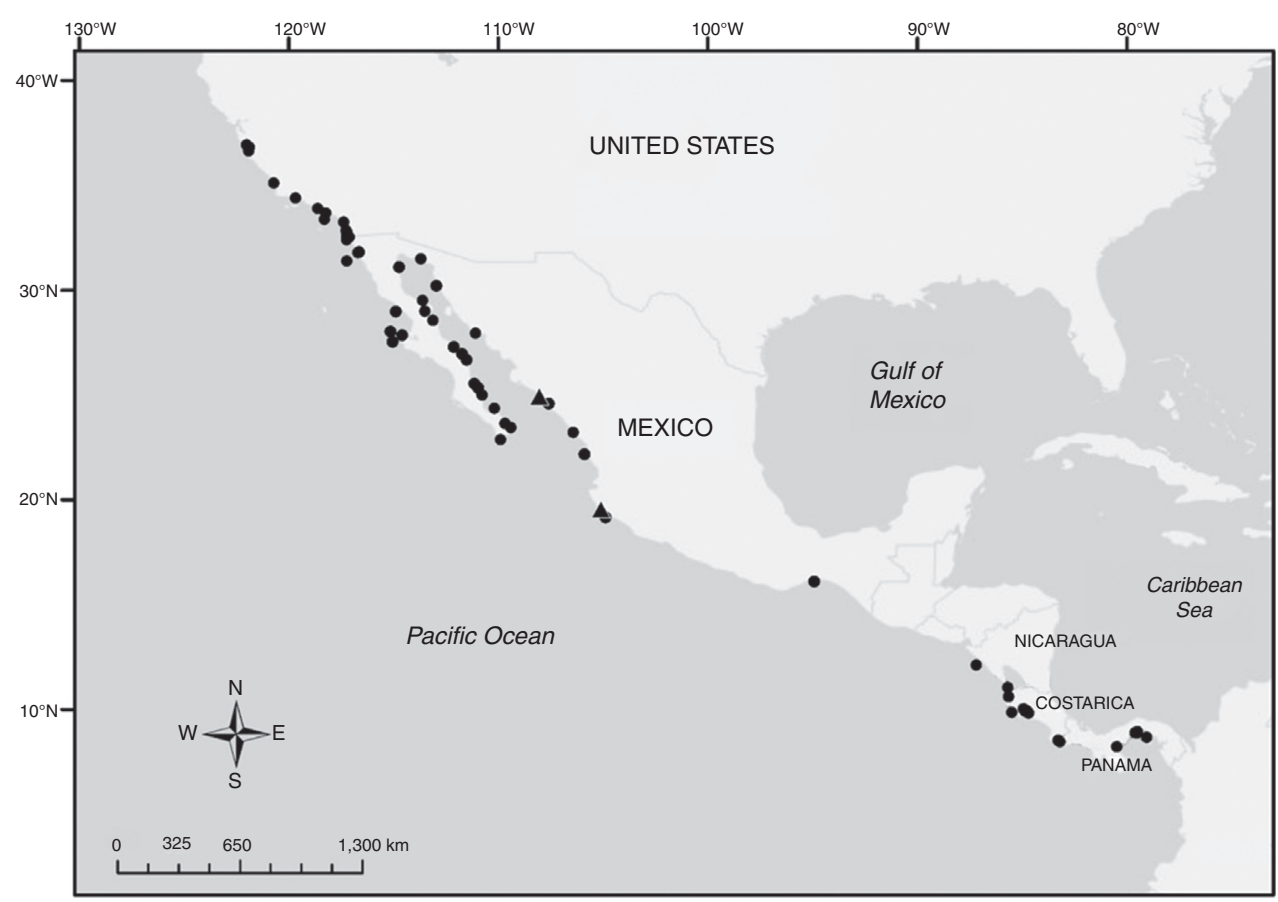

Figure 2. Map displaying records of Branchiostoma californiense based on previously known material (black circles) and the present study material (black triangles).

Table 1

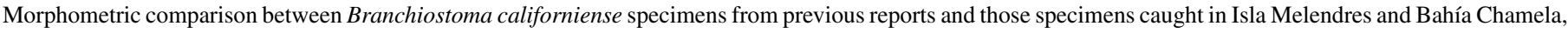
Mexico. Parentheses indicate average.

\begin{tabular}{|c|c|c|c|c|c|}
\hline & Kirkaldy (1895) & Hubbs (1922) & Poss and Boschung (1996) & Del Moral-Flores et al. (2016) & Present work \\
\hline Total length $(\mathrm{cm})$ & $7.4 \max$. & $3.75-8.35$ & No data & $8.35 \mathrm{~mm}$ & $2.41-4.01$ \\
\hline Dorsal fin-chambers & No data & $312-374(337)$ & $317-419(355)$ & $317-419(355)$ & $343-395(364)$ \\
\hline Preanal fin-chambers & No data & 50 & $35-59(44)$ & $35-59(44)$ & $56-61(58)$ \\
\hline $\begin{array}{l}\text { Relative length of } \\
\text { preatrioporal region to } \\
\text { postatrioporal region }\end{array}$ & No data & $2.65-3.3$ & No data & No data & $2.2-2.6(2.42)$ \\
\hline Total myotomes & $69-73(71)$ & $68-74$ & $64-78(70.1)$ & $64-71(67)$ & $66-72(69)$ \\
\hline Preatriopore myotomes & $44-45$ & $43-48$ & $42-47(44.3)$ & $40-45(40)$ & $39-46(43)$ \\
\hline $\begin{array}{l}\text { Myotomes between } \\
\text { atriopore and anus }\end{array}$ & $16-19$ & $16-19$ & $13-19(16.7)$ & $14-19(18)$ & $16-19(17)$ \\
\hline Postanal myotomes & $8-9$ & $8-10$ & $7-11(9.1)$ & $8-9(9)$ & $9-10(9)$ \\
\hline Gonad pouches & 31 & $27-36(33)$ & $36 \max$. & 36 max. & $18-31(26)$ \\
\hline$N$ & 10 & 22 & 57 & No data & 5 \\
\hline
\end{tabular}

southern California (USA), Gulf of California (Mexico), and Central America (from Nicaragua to Panama) with a great gap without records between the last 2 regions. Possibly the absence of records between the Gulf of California and Nicaragua is due to the lack of sampling effort on this group in this large area of over 2,800 km of coastline (Bastida-Zavala et al., 2013; Del Moral-Flores et al., 2016; Fuentes-Farías, Villaroel-Melo, \& Solís-Marín, 2005).

Poss and Boschung (1996) recognized great morphometric variation among specimens of $B$. californiense but without a well-defined geographic pattern. As expected, specimens from Bahía Chamela and Isla Melendres are similar to specimens of the Gulf of California (Mexico) and Central America (Nicaragua to Panama) but show some differences from the records from California (USA). The most remarkable difference between specimens from the Gulf of California and those recorded in
Bahía Chamela is in the number of preatriopore myotomes (42-47 and 39-46, respectively) (Table 1). There is also a tendency to increase the number of dorsal and preanal fin-chambers from the northern to the southern specimens recorded in Mexico. Hubbs (1922) measured less preanal fin-chambers (50 vs. 58) and presented lengths of mature specimens from 5.8 to $8.35 \mathrm{~cm}$ and immature specimens from 3.75 to $5.6 \mathrm{~cm}$, whereas we found a mature individual of $2.61 \mathrm{~cm}$. According to Hubbs, specimens from San Luis Gonzaga Bay, Gulf of California (collected by the Albatross), are not fully typical in the form of tail and fins, but differences may be due to the poor preservation of the gulf specimens. On the other hand, Kirkaldy (1895) reported $7.4 \mathrm{~cm}$ as the maximum size but did not report the minimum of specimens collected in California, USA. Specimens from Bahía Chamela are comparatively smaller than previous records from the California coast (Hubbs, 1922) but are of similar 
size $(5-37 \mathrm{~mm})$ to those collected in Costa Rica (Vargas \& Dean, 2010). In this case, Vargas and Dean (2010) reported that smaller individuals probably represent recruits for this species. However, specimens of Bahía Chamela are mature individuals and the lower number of gonad pouches compared to previous reports is likely due to their smaller size. More sampling effort should be performed in the southern Pacific coast of Mexico (between Colima and Chiapas) and in Central America (from Guatemala to El Salvador) to confirm if there is a continuous distribution of the Californian lancelet and to evaluate morphometric differences among populations. Besides, a phylogenetic study of these populations is also necessary to determine if they belong to only 1 species or are a complex of species such as was recently recorded for Asymmetron lucayanum (Kon, Nohara, Nishida, Sterrer, \& Nishikawa, 2006; Kon et al., 2007).

Thanks to Cristina Zuñiga, Valentina Fernández, Thalía González, Diego Moreno, Abel Trejo, and Cande Hernández for their help during sampling work. To Jorge Vega and all the personnel in the Biological Station of Chamela for access to the facilities. We are grateful to Adriana Reyes for taking pictures and to Stefanie Kaiser for comments on the final version of the manuscript. This work was supported by the Comisión Nacional para el Conocimiento y Uso de la Biodiversidad (Conabio) (grant number JF023) and the University of Guadalajara (grant number P3E2014).

\section{References}

Bastida-Zavala, J. R., García-Madrigal, M. S., Rosas-Alquicira, E. F., LópezPérez, R. A., Benítez-Villalobos, F., Meraz-Hernando, J. F., et al. (2013). Marine and coastal biodiversity of Oaxaca, Mexico. Check List, 9, 329-390.

Beebe, W., \& Tee-Van, J. (1941). Eastern Pacific expeditions of the New York Zoological Society. XXIV. Fishes from the tropical eastern Pacific (16from Cedros Island, Baja California 17Sur to the 18Galápagos Islands and northern Peru). Part 1. Lancelets and Hagfishes. Zoologica N.Y., 26, 89-91.

Da Silva, L. F. B., Tavares, M., \& Soares-Gomes, A. (2008). Population structure of the lancelet Branchiosotma caribaeum (Cephalochordata: Branchiostomidae) in the Bahía de Guanabara, Rio de Janeiro, southeastern Brazil. Revista Brasileira de Zoología, 25, 617-623.
Del Moral-Flores, L. F., Guadarrama-Martínez, M. Á., \& Flores-Coto, C. (2016). Composición taxonómica y distribución de los cefalocordados (Cephalochordata: Amphioxiformes) en México. Latin American Journal of Aquatic Research, 44, 497-503.

Fuentes-Farías, A. L., Villaroel-Melo, M. D., \& Solís-Marín, F. A. (2005). Los invertebrados marinos. In G. L. E. Villaseñor (Ed.), La biodiversidad en Michoacán: estudio de estado (pp. 85-87). México D.F.: Comisión Nacional para el Conocimiento y Uso de la Biodiversidad, Secretaría de Urbanismo y Medio Ambiente, Universidad Michoacana de San Nicolás de Hidalgo, Mich.

García-Fernández, J., \& Benito-Gutiérrez, E. (2009). It's a long way from amphioxus: descendants of the earliest chordate. BioEssays, 31, 665-675.

Gee, H. (2006). Careful with that amphioxus. Nature, 439, 923-924.

Gill, T. (1895). The genera of Branchiostomidae. The American Naturalist, 29, 457-459.

Hubbs, C. L. (1922). A list of the lancelets of the world with diagnoses of five new species of Branchiostoma. Occasional Papers of the Museum of Zoology University of Michigan, 105, 1-15.

Kirkaldy, J. W. (1895). A revision of the genera and species of the Branchiostomidae. Quarterly Journal of Microscopical Science, 37, 303-323.

Kon, T., Nohara, M., Nishida, M., Sterrer, W., \& Nishikawa, T. (2006). Hidden ancient diversification in the circumtropical lancelet Asymmetron lucayanum complex. Marine Biology, 149, 875-883.

Kon, T., Nohara, M., Yamanoue, Y., Fujiwara, Y., Nishida, M., \& Nishikawa, T. (2007). Phylogenetic position of a whale-fall lancelet (Cephalochordata) inferred from whole mitocondrial genome sequences. BMC Evolutionary Biology, 7, 1-127.

Meek, S. E., \& Hildebrandt, S. F. (1923). Marine fishes of Panama. Part 1. Field Museum of Natural History, Publs 215, Zoology Series, 15, 1-330.

Poss, S. G., \& Boschung, H. T. (1996). Lancelets (Cephalochordata: Branchiostomatidae): how many species are valid? Israel Journal of Zoology, 42, S13-S66.

Richardson, B. J., \& McKenzie, A. M. (1994). Taxonomy and distribution of Australian cephalochordates (Chordata: Cephalochordata). Invertebrate Systematics, 8, 1443-1459.

Snodgrass, R. E., \& Heller, E. (1905). Shore fishes of the Revillagigedo, Clipperton, Cocos and Galápagos Islands. Proceedings of the Washington Academy of Sciences, 6, 333-427.

Vargas, J. A., \& Dean, H. K. (2010). On Branchiostoma californiense (Cephalochordata) from the Gulf of Nicoya estuary, Costa Rica. Revista de Biología Tropical, 58, 1143-1148.

Vergara, M., Oliva, M. E., \& Riascos, J. M. (2012). Population dynamics of the amphioxus Branchiostoma elongatum from northern Chile. Journal of the Marine Biological Association of the United Kingdom, 92, 591-599. 